\section{Rain Garden Filter Bed Substrates Affect Stormwater Nutrient Remediation}

\author{
Rebecca L. Turk ${ }^{1}$ and Helen T. Kraus ${ }^{2,6}$ \\ Department of Horticultural Science, North Carolina State University, \\ Kilgore Hall Box 7609, Raleigh, NC 27695-7609
}

Ted E. Bilderback ${ }^{3}$

J.C. Raulston Arboretum, North Carolina State University, Raleigh, NC 27695-7609

\section{William F. Hunt ${ }^{4}$ \\ Department of Biological and Agricultural Engineering: Urban Stormwater Management, North Carolina State University, Raleigh, NC 27695-7609}

\author{
William C. Fonteno ${ }^{5}$ \\ Department of Horticultural Science, North Carolina State University, \\ Raleigh, NC 27695-7616
}

\begin{abstract}
Additional index words. $\mathrm{N}$ concentration, $\mathrm{P}$ concentration, stormwater control measure, Magnolia virginiana (sweet bay magnolia), Magnolia virginiana 'Sweet Thing', Betula nigra (river birch), Betula nigra 'Duraheat', Viburnum nudum (possumhaw), Viburnum nudum 'Winterthur', Itea virginica (Virginia sweetspire), Itea virginica 'Henry's Garnet', Helianthus angustifolius (swamp sunflower), Helianthus angustfolius 'First Light', Eupatorium purpureum subsp. maculatum (Joe pye weed), E. purpureum subsp. maculatum 'Gateway', Juncus effusus (common rush), Juncus effusus 'Frenzy', Panicum virgatum (switch grass), Panicum virgatum 'Shenandoah'
\end{abstract}

\begin{abstract}
Twelve rain gardens were constructed to analyze the effectiveness of three different filter bed substrates to support plant growth and remove nutrients from urban stormwater runoff. The filter bed substrates included a sand-based substrate (sand) composed of $(\mathrm{v} / \mathrm{v} / \mathrm{v})$ of $80 \%$ washed sand, $15 \%$ clay and silt fines, and $5 \%$ pine bark; a soil-based substrate (soil) composed of (v/v) $50 \%$ sandy loam soil and $50 \%$ pine bark; and a slate-based substrate (slate) composed of (v/v) $80 \%$ expanded slate and $20 \%$ pine bark. Coarse particles $(6.3$ to $2.0 \mathrm{~mm})$ in the soil-based substrate created a large-pore network that conducted stormwater more quickly into and through the rain garden than slate or sand as evidenced by the high infiltration and saturated hydraulic conductivity values. Sand had good overall retention of pollutants except nitrogen $(\mathrm{N})$ possibly as a result of the very small percentage $(5 \%)$ of organic matter and low cation exchange capacity (CEC). Soil had the lowest remediation of phosphorus (P) and highest concentration of $P$ in its effluent and was similar in $N$ removal efficiency to slate. Slate had the best retention of $N$ and $P$. Overall, all three substrates functioned in reducing the quantity of pollutants in urban stormwater runoff; yet, the impact of substrate on remediation appeared to lessen by Season 2 because there were few differences between substrate in the effluent nutrient concentration. Substrate did not affect shoot or root growth. Eleven of the 16 species (B. nigra, B. 'Duraheat', M. virginiana, M. 'Sweet Thing', I. virginica, I. 'Henry's Garnet', J. effusus, $P$. 'Shenandoah', H. angustifolius, H. 'First Light', and $E$. purpureum subsp. maculatum) grew well in the rain gardens and could be used as rain garden plants.
\end{abstract}

Water is one of the planet's most precious resources, yet it has become one of the most polluted and neglected [U.S. Environmental Protection Agency (EPA), 2009]. Nationally, urban stormwater runoff is listed in the top 10 causes of river, stream, lakes, ponds, reservoirs, bays, and estuary impairments (U.S. EPA, 2009). In North Carolina, sedimentladen urban stormwater runoff poses the largest threat to water quality (U.S. EPA, 2009). Pollutants of concern in urban stormwater runoff are bacteria, $\mathrm{N}\left[\mathrm{NH}_{4}\right.$ (ammonium), $\mathrm{NO}_{2}{ }^{-}$(nitrite), and $\mathrm{NO}_{3}{ }^{-}$(nitrate, most hydraulic conductivity (Ksat) and infiltration and low organic matter content, then planted with vegetation that aids in the removal of pollutants [Davis et al., 2009; Hunt et al., 2012; North Carolina Division Environment and Natural Resources (NCDENR), 2007]. By increasing infiltration and evapotranspiration, rain gardens have the capability to reduce peak flows, volumes of runoff, and water pollution more effectively than other stormwater control measures (Davis et al., 2009; Hunt et al., 2012; Passeport et al., 2009). The majority of rain garden research has been conducted by agricultural and environmental engineers to evaluate the structural design and water flow properties of rain gardens. Because chosen plant materials and garden aesthetics are crucial components of success and acceptance by the general public of these stormwater control measures, a horticultural consideration of the substrates used to support plant growth is also needed.

Physical properties (infiltration, Ksat, and moisture retention) and chemical properties (adsorption and fixation) are all important characteristics of a well-functioning rain garden filter bed substrate. The particle size, shape, and ratio of components in the substrate will determine the substrate's Ksat, water-holding capacity, and re-aeration rates (Drzal et al., 1999). Coarse particles (6.3 to $2 \mathrm{~mm}$ ) create large pores within the substrate and establish a pore network that conducts water through the substrate (Drzal et al., 1999). The medium particles ( 2.0 to $0.5 \mathrm{~mm}$ ) retain water and contribute to increased total porosity, whereas the fine $(0.5$ to $0.106 \mathrm{~mm})$ particles nest into larger pores and also retain water against leaching (Drzal et al., 1999). Ksat values of a rain garden vary (1.0 to 30.6 $\mathrm{cm} \cdot \mathrm{h}^{-1}$ ) depending on filter bed substrates used (Hsieh et al., 2007a; Hunt et al., 2012; NCDENR, 2007; Passeport et al., 2009; U.S. EPA, 1998). Ksat should be 1 to $2 \mathrm{~cm} \cdot \mathrm{h}^{-1}$ for nutrient removal in substrates composed of a sand-based substrate that also includes $8 \%$ to $12 \%$ fines (clay and silt) and $3 \%$ to $5 \%$ organic matter (NCDENR, 2007). Working with an expanded slate substrate $(80 \%$ expanded slate, 15\% sand, and 5\% topsoil), Passeport et al. (2009) reported a Ksat of 15 $\mathrm{cm} \cdot \mathrm{h}^{-1}$ but speculated that Ksats should have been lower when nutrient loads were higher. A substrate with a high Ksat overlaying one with a low Ksat (resulting in an overall Ksat of $30 \mathrm{~cm} \cdot \mathrm{h}^{-1}$ ) was most efficient for P remediation (Hsieh et al., 2007a). Metals, oils, and hydrocarbons are easily removed with a higher Ksat rate $\left(14.4 \mathrm{~cm} \cdot \mathrm{h}^{-1}\right)$, whereas $\mathrm{P}$, $\mathrm{N}$, pathogens, and total soluble salts are best removed with lower rates $\left(2.5 \mathrm{~cm} \cdot \mathrm{h}^{-1}\right)$ (Hunt et al., 2012).

Nutrient removal efficiencies of a rain garden have improved for ammonium, total $\mathrm{N}$, and total Kjeldahl $\mathrm{N}$ as research has refined substrate and engineering principles, but removal efficiencies remain low for nitrate-N (Davis et al., 2009). Overall, nitrate is the most difficult form of $\mathrm{N}$ to remove from stormwater because it does not bind to most soils or substrates (Davis et al., 2009). Many 
researchers have reported either little or no nitrate- $\mathrm{N}$ removal or reported few data to prove good removal percentages of nitrate- $\mathrm{N}$ (Hsieh et al., 2007b; Hsieh and Davis, 2005; Hunt et al., 2008; Passeport et al., 2009). However, a rain garden containing a sandy loam filter bed substrate with a $\mathrm{pH}$ of 6.4 , CEC of $2.9 \mathrm{meq} / 100 \mathrm{~g}$, and $0.6 \%$ organic matter had nitrate and nitrite mass removals up to $80 \%$ and was significant in the overall removal of nitrogen (68\% to $75 \%$ ) from stormwater runoff (Kim et al., 2003).

Phosphorus removal from stormwater is determined by the substrate's P content and adsorption and fixation capabilities. Removal efficiencies for filter bed substrates containing a sandy loam or loamy sand soil with high $\mathrm{P}$ content were poor as a result of desorption of $\mathrm{P}$ from the substrate (Dietz and Claussen, 2005; Hunt et al., 2006). In addition to adsorption, $\mathrm{P}$ may be fixed (removed from solution as a precipitate) by cation- $\mathrm{PO}_{4}$ complexing. Lucas and Greenway (2008) reported P complexing with iron in a loam-based substrate. Increased stormwater retention time (low Ksat) enhances these complexes and reduces $\mathrm{P}$ export.

Filter bed substrate composition and stormwater retention also affect removal of metals. Metals are efficiently removed by sand-based rain gardens as a result of the low Ksat that these substrates provide (Glass and Bissouma, $2005)$. The majority of metals ( $88 \%$ to $97 \%)$ are bound within the substrate, not taken up by the plant ( $1 \%$ to $3 \%$ ) (Sun and Davis, 2007). Slow Ksats, which reduce water loss between rain events, increased metal remediation, in particular copper (Blecken et al., 2009a, 2009b).

The filter bed substrate is the foundation of the rain garden and gives it the ability to infiltrate runoff, slow drainage, support plant growth, and remove pollutants (Davis et al., 2009; Hunt et al., 2012; Lucas and Greenway, 2008). This experiment was designed to assess three different filter bed substrates for

Received for publication 8 Nov. 2013. Accepted for publication 4 Mar. 2014.

This research was funded in part by grants from the North Carolina Nursery and Landscape Association, Raleigh, NC, and donations by Wade Moore Equipment Company, Louisburg, NC; Oldcastle, Louisburg, NC; and Carolina Stalite Company, Salisbury, NC. Plants were donated by Carolina Native Nursery, Burnsville, NC; Classic Viburnums, Upland, NE; ERNST Conservation Seeds, Meadville, PA; Fairview Greenhouses and Garden Center, Raleigh, NC; Griffith Propagation Nursery, Watkinsville, GA; Hawksridge Nursery, Hickory, NC; Hidden Hollow Nursery, Belvidere, TN; Hoffman Nursery, Bahama, NC; Jelito Seed, Louisville, KY; North Creek Nurseries, Landenber, PA; and Worthington Farms, Greenville, NC.

${ }^{1}$ Graduate Student.

${ }^{2}$ Assistant Professor

${ }^{3}$ Professor and Director.

${ }^{4}$ Professor and Extension Specialist.

${ }^{5}$ Professor.

${ }^{6}$ To whom reprint requests should be addressed; e-mail Helen_Kraus@ncsu.edu. their effectiveness in nutrient removal and supporting plant growth.

\section{Materials and Methods}

Twelve rain gardens were constructed, filled with one of three filter bed substrates (soil, sand, and slate, see descriptions below), planted with sixteen species, and irrigated with stormwater. The experiment was conducted from 29 June 2011 to 12 July 2012 and was a completely randomized design with treatments represented four times.

Rain garden construction. Construction on the 12 rain gardens began on 1 Feb. 2011 and concluded on 25 Mar. 2011. Each rain garden was $1.8 \mathrm{~m}$ wide $\times 9.8 \mathrm{~m}$ long $\times 1.2 \mathrm{~m}$ deep with a substrate volume of $15.3 \mathrm{~m}^{3}$. A 0.9-m raised berm covered with weed fabric was built between each bed. Rain gardens were dug to have a slight internal slope of $2 \%$. Before filling each rain garden, a $10.2-\mathrm{cm}$ wide filter sock-covered, slotted corrugated pipe (effluent catchment pipe) was placed horizontally at the bottom to capture and transfer water that filtered through the substrate and reached the bottom of each rain garden (effluent) out of the rain garden into a collection tub. A 15.2-cm layer of gravel in the soil and sand filter bed substrates and permatill (size CA-9) in the slate substrate was placed over each of the effluent catchment pipes. All rain gardens had $0.2 \mathrm{~m}$ of gravel or permatill over the pipe and $1.1 \mathrm{~m}$ of substrate. Three treated $2.5 \mathrm{~cm} \times 15.2 \mathrm{~cm} \times 182.9-\mathrm{cm}$ boards were inserted $5.1 \mathrm{~cm}$ deep into each bed $3 \mathrm{~m}$ apart to create ponding zones along the sloped surface of the beds.

Filter bed substrates. Three commercially available, pre-blended filter bed substrates were evaluated, each with a different base component and the same source of organic matter (pine bark fines). The sand-based substrate (sand) was a blend (v/v/v) of $80 \%$ washed sand, $15 \%$ clay and silt fines, and $5 \%$ pine bark with a very low phosphorus content (Wade Moore Equipment Company, Louisburg, NC). This substrate was chosen to represent the commonly used rain garden filter bed substrate for North Carolina. The soil-based substrate (soil) was a blend (v/v) of $50 \%$ sandy loam soil and $50 \%$ pine bark with a low $\mathrm{P}$ content (although five times higher than sand) (Oldcastle, Louisburg, NC). This substrate was chosen to represent a potential residential rain garden filter bed substrate. The third substrate was a blend $(\mathrm{v} / \mathrm{v})$ of $80 \%$ expanded slate and $20 \%$ pine bark fines (slate) with a low P content (similar to soil and also five times higher than sand) (Carolina Stalite Company, Salisbury, NC). This locally produced slate substrate has become a popular rain garden filter bed substrate in North Carolina.

Plant material. Species evaluated included trees (Betula and Magnolia), shrubs (Viburnum and Itea), herbaceous perennials (Helianthus and Eupatorium), a grass (Panicum), and a rush (Juncus) and were used to consider a wide range of evergreen, deciduous, woody, and herbaceous plants for their garden performance. Each rain garden was planted with 36 total plants consisting of one of each tree, two of each of the shrubs and herbaceous perennials (placed at $121.9 \mathrm{~cm} \times$ 91.4-cm spacing), and three of each the grasses and rushes (planted at $91.4 \mathrm{~cm} \times$ 91.4-cm spacing). Magnolia virginiana L. (sweet bay magnolia), M. virginiana L. 'Sweet Thing', Betula nigra L. (river birch), B. nigra L. 'Duraheat', Viburnum nudum L. (possumhaw), V. nudum L. 'Winterthur', Itea virginica L. (Virginia sweetspire), I. virginica L. 'Henry's Garnet', Helianthus angustifolius L. (swamp sunflower), H. angustfolius 'First Light', Eupatorium purpureum subsp. maculatum (L.) Á. Löve \& D. Löve (Joe pye weed), E. purpureum subsp. maculatum (L.) Á. Löve \& D. Löve 'Gateway', Juncus effusus L. (common rush), J. effusus L. 'Frenzy', Panicum virgatum $\mathrm{L}$. (switch grass), and $P$. virgatum L. 'Shenandoah' were planted on 17 May 2011. All of the plants were donated from nurseries as potted plants except $H$. angustifolius L. and E. purpureum subsp. maculatum which were cultivated by the researchers from seed and planted as plugs. All plants were randomized and planted to their recommended depth. Plants were irrigated once a week for 6 weeks for establishment and then as described below.

A scale of 1 to 5 was used to assess health and garden performance of the plants where $1=$ dead (no living material), 2 = nearly dead and chlorosis/necrosis (greater than 50\%), $3=$ stunted growth and/or chlorosis/necrosis (less than $50 \%$ ), $4=$ chlorosis/necrosis (less than $10 \%$ ), 5 = excellent condition (good color and growth). These data were collected for each plant on 17 July, 26 Aug., and 7 Oct. 2011 and 10 May, 11 June, and 16 July 2012. At the conclusion of the study, all plants (shoot and root) were harvested from each rain gardens. On 16 July 2012, shoots (leaves + stems) were cut to $15.2 \mathrm{~cm}$ above the substrate. Roots were removed from each rain garden on 23 to 27 July 2012 using an air spade powered by a 185 Solar air compressor (Michigan City, IN). Roots were then washed free of remaining substrate with a highpressure stream of water. Shoots and roots were dried at $62{ }^{\circ} \mathrm{C}$ for $5 \mathrm{~d}$ and then weighed.

Stormwater source. Urban stormwater runoff including sediment was applied individually to each rain garden. The urban stormwater runoff was pumped from a catchment pond and originated from hardscapes and cultivated vegetated areas. Centrally located near the 12 rain gardens, a $2.1 \mathrm{~m} \times$ $11.0 \mathrm{~m} \times 1.4-\mathrm{m}(16,141-\mathrm{L})$ pit was dug and lined with pond liner. This pit was filled with water from the catchment pond using a nonfiltered pump (Professional Well-X-Trol, 125 psi Amtrol pump Model WX-302; Amtrol Company, West Warwick, RI). Approximately $1135.5 \mathrm{~L}\left(25.4 \mathrm{~mm} / 17.8 \mathrm{~m}^{2}\right)$ of stormwater was applied over the entire area of each individual rain garden using a sump pump (Model FP0S3200A-09, Flotec; Pentair Company, Delavan, WI) that provided $13,741 \mathrm{~L} \cdot \mathrm{h}^{-1}$ and three MintCraft ${ }^{\mathrm{TM}}$ rectangle pattern metal sprinklers installed down the center of each 
rain garden (sprinklers were placed every $3.0 \mathrm{~m}$ ). A Netafilm flow meter (Models M-1in-10-92178 and M-1-in-11-92765; Netafilm USA, Fresno, CA) was installed to measure stormwater volume applied to each garden. Stormwater was applied to the rain gardens every 2 weeks during the summer (29 June through 6 Oct. 2011 and 4 Apr. through 23 July 2012) and once a month during the winter (3 Nov. 2011 through 1 Mar. 2012). The volume and frequency of stormwater application was used to mimic the annual rainfall of Raleigh, NC, in 1 year.

Average total $\mathrm{N}$ and $\mathrm{P}$ concentrations in polluted stormwater runoff are $1.1 \mathrm{mg} \cdot \mathrm{L}^{-1} \mathrm{~N}$ and $0.14 \mathrm{mg} \cdot \mathrm{L}^{-1} \mathrm{P}$ (Passeport et al., 2009). Measured nutrient concentrations in this project's urban stormwater runoff were quite variable but averaged $8.8 \pm 16.5 \mathrm{mg} \cdot \mathrm{L}^{-1} \mathrm{~N}$ and $2.1 \pm 3.7 \mathrm{mg} \cdot \mathrm{L}^{-1} \mathrm{P}$ during the study. However, concern over measurable $\mathrm{N}$ and $\mathrm{P}$ concentration in the effluent resulted in the higher concentrations $\left(50 \mathrm{mg} \cdot \mathrm{L}^{-1} \mathrm{~N}\right.$ and 50 $\left.\mathrm{mg} \cdot \mathrm{L}^{-1} \mathrm{P}\right)$ being applied in this project. Ammonium sulfate and diammonium phosphate (to provide $50 \mathrm{mg} \cdot \mathrm{L}^{-1} \mathrm{~N}$ and $50 \mathrm{mg} \cdot \mathrm{L}^{-1}$ P) were dissolved in $18.9 \mathrm{~L}$ of hot water before adding to the pit as it was filled with the urban stormwater runoff. Actual $\mathrm{N}$ and $\mathrm{P}$ concentrations in the stormwater applied (nutrients in stormwater + fertilizer) to the rain gardens averaged $80.9 \pm 22.1 \mathrm{mg} \cdot \mathrm{L}^{-1} \mathrm{~N}$ and $14.6 \pm 5.5 \mathrm{mg} \cdot \mathrm{L}^{-1} \mathrm{P}$. The authors hypothesize that some of the $\mathrm{P}$ was bound to the sediment in the stormwater before application, hence the lower than targeted $\mathrm{P}$ concentrations being applied. Measured rainfall during this study was $12.2,4.8,8.4,23.4,15.5$, 7.4, 10.0, 5.3, 6.4, 7.1, 15.7, 5.9, 16.6, 10.9, and $20.6 \mathrm{~cm} /$ month for May 2011 through July 2012, respectively.

Effluent nutrient analysis. Total volume of effluent was not measured. However, the effluent catchment pipe for each rain garden ended into a tub and an effluent sample was collected from each rain garden at each simulated rainfall event on 29 June, 13 July, 27 July, 10 Aug., 25 Aug., 8 Sept., 20 Sept., and 6 Oct. 2011 (Season 1) and 5 Apr., 18 Apr., 3 May, 17 May, 28 May, 14 June, 28 June, and 12 July 2012 (Season 2). The winter (dormant) season samples were taken on 3 Nov., 1 Dec. 2011, 12 Jan., 2 Feb., and 1 Mar. 2012. A stormwater sample was collected from the water pit before fertilizer was added, after fertilizer was added, and from each bed through the effluent catchment pipe, totaling 14 samples per stormwater application. Samples were frozen before being submitted to the North Carolina Department of Agriculture and Consumer Services (Agronomic Division, Raleigh, NC) for inorganic nitrogen (IN-N), urea, $\mathrm{P}$, potassium $(\mathrm{K})$, calcium $(\mathrm{Ca})$, magnesium $(\mathrm{Mg})$, sulfur $(\mathrm{S})$, boron $(\mathrm{B})$, copper $(\mathrm{Cu})$, iron $(\mathrm{Fe})$, manganese $(\mathrm{Mn})$, and zinc $(\mathrm{Zn})$ analyses. IN-N included nitrate $\left(\mathrm{NO}_{3}-\mathrm{N}\right)+$ nitrite $\left(\mathrm{NO}_{2}-\mathrm{N}\right)+$ ammonium $\left(\mathrm{NH}_{4}-\mathrm{N}\right) \mathrm{N}$. $\mathrm{NO}_{3}-\mathrm{N}$ is determined on a homogenized sample $(\approx 20 \mathrm{~mL})$ by nitrate-hydrazine reduction (Kempers and Luft, 1988; Skalar Analytical B.V., 1995b) and $\mathrm{NH}_{4}-\mathrm{N}$ is de- termined by a modified Berthelot reaction (adapted from Krom and Bemer, 1980; Skalar Analytical B.V., 1995a) with an autoflow spectrophotometric analyzer $\left(\mathrm{San}^{++}\right.$ Segmented Flow Auto-Analyzer; Skalar Instruments, Breda, The Netherlands). Total concentrations of $\mathrm{P}, \mathrm{K}, \mathrm{Ca}, \mathrm{Mg}, \mathrm{S}, \mathrm{Fe}, \mathrm{Mn}, \mathrm{Zn}$, $\mathrm{Cu}$, and $\mathrm{B}$ are determined with an inductively coupled plasma (ICP) spectrophotometer (Optima 3300 DV ICP emission spectrophotometer; Perkin Elmer Corporation, Shelton, $\mathrm{CT})$. Remediation efficiencies [(nutrient concentration in simulated runoff - nutrient concentration in effluent) $\div$ nutrient concentration in simulated runoff] were calculated and used for substrate comparisons because nutrient content (volume of effluent $x$ nutrient concentration in the effluent) could not be calculated.

Substrate physical properties. All physical property analyses were conducted at the North Carolina State University (NCSU) Horticultural Substrates Laboratory, Department of Horticultural Science, Raleigh except infiltration and bulk density, which were determined in situ. Particle size determination for each rain garden substrate was measured on 19 Aug. 2011. Approximately $350 \mathrm{~g}$ of each substrate was dried at $105{ }^{\circ} \mathrm{C}$ for $48 \mathrm{~h}$ then shaken for $5 \mathrm{~min}$ in a Ro-tap Shaker (Model B; W.S. Tyler, Mentor, $\mathrm{OH}$ ) fitted with 13 sieve plates: $6.3 \mathrm{~mm}, 4.0 \mathrm{~mm}, 2.8 \mathrm{~mm}, 2.0 \mathrm{~mm}, 1.4$ $\mathrm{mm}, 1.0 \mathrm{~mm}, 0.71 \mathrm{~mm}, 0.5 \mathrm{~mm}, 0.36 \mathrm{~mm}$, $0.25 \mathrm{~mm}, 0.18 \mathrm{~mm}$, and $0.106 \mathrm{~mm}$. The portion of the sample collected on each sieve plate was weighed and expressed as a percentage of the total weight of the sample. Percentages of total sample were then grouped into fine (less than $0.5 \mathrm{~mm}$ ), medium ( 0.5 to $2.0 \mathrm{~mm}$ ), and coarse (greater than $2.0 \mathrm{~mm}$ ) fractions as described by Drzal et al. (1999) for statistical analyses. Hydraulic conductivity was measured for eight replications of each substrate on 4 Aug. 2011 using the NCSU Ksat unit (Drzal et al., 1999). Hydraulic conductivity determines the rate at which the stormwater travels through the saturated substrate $\left(\mathrm{cm} \cdot \mathrm{h}^{-1}\right)$.

On 11 May 2011 (7 weeks after filling the rain gardens with the substrate and before planting), initial infiltration was determined using a double-ring infiltrometer. Infiltration was also determined at the end of season one on 5 Oct. 2011, 28 weeks after filling and with plants growing for $141 \mathrm{~d}$. The beginning of Season 2, infiltration was determined on 28 Mar. 2012 and the end of Season 2, infiltration was measured on 19 July 2012. For all infiltration sample times, two metal cylinders (one inside the other) were inserted $3.8 \mathrm{~cm}$ into the substrate and infiltration of water in the inner ring was recorded in sec. $\mathrm{cm}^{-1}$. Two infiltration rates were averaged for each rain garden. Infiltration measurements were determined by the same plant species in each bed to ensure similar root densities. Stormwater flow characteristics across the surface and through each rain garden (flush event) were measured on 1 Sept., 15 Sept., and 27 Sept. 2011 and 14 May, 25 June, and 13 July 2012. Stormwater runoff was applied to the top of the slope of each rain garden using the sump pump and an open $2.54-\mathrm{cm}$ polyethylene pipe and time needed for effluent to begin to occur was recorded.

Bulk density $\left(\mathrm{g} \cdot \mathrm{cm}^{-3}\right)(\mathrm{BD})$ and moisture content (MC) were determined on 1 Sept. 2011 (22 weeks after filling each rain garden bed) and 14 July 2012 (67 weeks after filling each rain garden bed). Bulk density was measured in situ using an Uhland sampler to obtain undisturbed cores $\left(347.5 \mathrm{~cm}^{3}\right)$ of substrate. On 1 Sept. 2011, two samples were taken from each bed. Differences between the BD samples within a bed taken on 1 Sept. 2011 were not significant so on 14 July 2012 , only one sample was taken per bed. The wet weight of the substrate in the cores was recorded then cores were dried at $105{ }^{\circ} \mathrm{C}$ for $48 \mathrm{~h}$. Moisture content was determined by subtracting the dry weight from the wet weight and dividing by the core volume.

Substrate chemical properties. Substrate samples of each bed were taken on 28 June 2011 (initial) before simulated rainfall events began and then on 14 July 2012 (final) after all rainfall events had concluded. On 28 June 2011, subsamples were taken with soil probe at $0.3-\mathrm{m}$ intervals to a total depth of $0.91 \mathrm{~m}$. Three samples (nine total subsamples) were taken per bed. Differences between the subsample depths were non-significant, so final substrate samples were only taken at a $0.6-\mathrm{m}$ depth, one sample per bed. All samples were analyzed at the North Carolina Department of Agriculture Soil and Plant Analysis Laboratory, Raleigh, NC. Substrate samples were dried at $62{ }^{\circ} \mathrm{C}$ for $5 \mathrm{~d}$, ground in a hammermill, and sieved through an 18-mesh (1-mm) screen. Each substrate sample $(1.25 \mathrm{~g})$ was combusted at $490{ }^{\circ} \mathrm{C}$ for $6 \mathrm{~h}$ The resulting ash was dissolved in $10 \mathrm{~mL} 6 \mathrm{~N} \mathrm{HCl}$ and diluted to $50 \mathrm{~mL}$ with distilled deionized water. $\mathrm{P}$ concentrations were determined by a P-2000 ICP emissions spectrophotometer (Perkin Elmer, Norwalk, CT). N concentration was determined using $10 \mathrm{mg}$ samples in a Perkin Elmer $2400 \mathrm{CHN}$ elemental analyzer.

The study was conducted at the Horticulture Field Laboratories, Raleigh, NC (long. $35^{\circ} 47^{\prime} 29.57^{\prime \prime} \mathrm{N}$; lat. $78^{\circ} 41^{\prime} 56.71^{\prime \prime} \mathrm{W}$; elevation: $136 \mathrm{~m}$ ). SAS 9.2 was used to test all variables for differences using analysis of variance procedures and Fisher's protected least significance differences means separation procedures $(P \leq 0.05)$ where appropriate (SAS Institute, Inc., 2001).

\section{Results and Discussion}

Substrate physical properties. The engineered substrates used in this project were composed of different component mixtures and therefore particle size distribution varied among substrates (Table 1). As a result of its higher amount $(50 \%)$ of pine bark, soil had greater percentages of large particles (greater than $6.3 \mathrm{~mm}$ ) followed by slate and sand. Sand had a greater percentage of particles in the $1.0-$ to $0.18-\mathrm{mm}$ range than both soil and slate. Slate had the greatest percentage of particles in the 2.8 - to $1.0-\mathrm{mm}$ range followed 
by sand and then soil. The small particles (less than $0.106 \mathrm{~mm}$ ) were lower in sand and soil than slate. However, significances in particle size distributions such as these are not easily translated into water flow differences through the engineered substrates. The blended substrate's Ksat, moisture retention, and re-aeration rates may be better predicted by groupings of particles into coarse (6.3 to $2.0 \mathrm{~mm}$ ), medium (2.0 to $0.5 \mathrm{~mm}$ ), and fine ( 0.5 to $0.106 \mathrm{~mm})$ particle size ranges as described by Drzal et al. (1999). Soil had twice the percentage of particles in the coarse range than either slate or sand (Table 1). Similar to Drzal et al. (1999) and Kraus et al. (2013), these coarse particles appear to have created a large pore network for conducting stormwater into and through the substrate as evidenced by the high infiltration and Ksat values of the soil substrate (Table 2). Fifty percent of slate particles were in the medium range with soil having the least at $41 \%$ (Table 1). These medium-sized particles retain larger amounts of water and increase overall porosity of the substrate (Drzal et al.,
1999). Sand and slate had similar percentages of fine particles (Table 1) and similar MCs (Table 2). Soil and slate had the greatest percentage of particles in the coarse and medium ranges $(78 \%$ and $67 \%$ for soil and slate, respectively) and also had the fastest drainage rates as measured by the flush events. On average, soil took $13.5 \mathrm{~min}$ and slate $16.2 \mathrm{~min}$ for stormwater applied to the surface of the filter bed substrate to discharge from the effluent catchment pipe. During a flush event, sand took, on average, $27.4 \mathrm{~min}$ for stormwater to infiltrate and drain from the effluent collection pipe as a result of smaller pore sizes.

Infiltration changed at each sample date from initial through the end of the study (Table 2). Initial infiltration (7 weeks after filling the rain gardens and pre-plant) was fastest with the soil and was slowest with sand. Hsieh and Davis (2005) also found that substrates with larger particle sizes, like the soil in our study, resulted in higher infiltration and higher Ksat. At the end of Season 1 (28 weeks after filling with plants growing for $141 \mathrm{~d})$, the comparisons of means between

Table 1. Particle size distribution of rain garden filter bed substrates.

\begin{tabular}{|c|c|c|c|c|c|}
\hline \multirow{2}{*}{$\begin{array}{l}\text { Particle } \\
\text { size (mm) }\end{array}$} & \multirow{2}{*}{$\begin{array}{c}\text { Analysis } \\
\text { of variance }\end{array}$} & Soil $^{y}$ & Slate & Sand & \multirow{2}{*}{$\begin{array}{c}\text { Particle } \\
\text { size range }\end{array}$} \\
\hline & & \multicolumn{3}{|c|}{ (\% of dry wt) } & \\
\hline$>6.3$ & 0.003 & $11.9 \mathrm{a}^{\mathrm{w}}$ & $0.4 \mathrm{~b}$ & $1.4 \mathrm{~b}$ & \\
\hline 6.3 to 4.00 & 0.0001 & $8.6 \mathrm{a}$ & $1.2 \mathrm{~b}$ & $4.8 \mathrm{a}$ & Coarse \\
\hline 4.00 to 2.80 & 0.001 & $7.8 \mathrm{a}$ & $4.5 \mathrm{~b}$ & $5.0 \mathrm{~b}$ & \\
\hline 2.80 to 2.00 & 0.0001 & $9.2 \mathrm{~b}$ & $10.0 \mathrm{a}$ & $6.3 \mathrm{c}$ & \\
\hline Total coarse & & $37.3^{* v}$ & $16.1 * *$ & $17.5^{* *}$ & \\
\hline 2.00 to 1.40 & 0.0001 & $12.5 \mathrm{~b}$ & $15.1 \mathrm{a}$ & $9.3 \mathrm{c}$ & \\
\hline 1.40 to 1.00 & 0.0001 & $11.5 \mathrm{~b}$ & $13.6 \mathrm{a}$ & $11.4 \mathrm{c}$ & Medium \\
\hline 1.00 to 0.71 & 0.0001 & $9.1 \mathrm{c}$ & $12.4 \mathrm{~b}$ & $13.8 \mathrm{a}$ & \\
\hline 0.71 to 0.50 & 0.0001 & $7.7 \mathrm{c}$ & $10.0 \mathrm{~b}$ & $13.8 \mathrm{a}$ & \\
\hline Total medium & & $39.8 * *$ & $51.1^{*}$ & $48.2 *$ & \\
\hline 0.500 to 0.355 & 0.0001 & $5.1 \mathrm{c}$ & $7.1 \mathrm{~b}$ & $11.8 \mathrm{a}$ & \\
\hline 0.360 to 0.250 & 0.0001 & $3.7 \mathrm{c}$ & $5.6 \mathrm{~b}$ & $9.5 \mathrm{a}$ & \\
\hline 0.250 to 0.180 & 0.0001 & $2.9 \mathrm{c}$ & $4.1 \mathrm{~b}$ & $5.5 \mathrm{a}$ & Fine \\
\hline 0.180 to 0.106 & 0.02 & $2.8 \mathrm{~b}$ & $5.0 \mathrm{a}$ & $2.9 \mathrm{~b}$ & \\
\hline$<0.106$ & 0.0001 & $6.8 \mathrm{~b}$ & $11.17 \mathrm{a}$ & $4.2 \mathrm{~b}$ & \\
\hline Total fine & & $21.4 * *$ & $33.0 *$ & $33.4^{*}$ & \\
\hline
\end{tabular}

${ }^{\mathrm{z}}$ Analysis of variance. $P$ values given.

${ }^{\mathrm{y}}$ Filter bed substrate blends $(\mathrm{v} / \mathrm{v})$. Soil $=50 \%$ sandy loam, $50 \%$ pine bark; sand $=80 \%$ sand, $15 \%$ clay and silt fines, $5 \%$ pine bark; slate $=80 \%$ expanded slate, $20 \%$ pine bark.

${ }^{\mathrm{x}}$ As classified by Drzal et al. (1999).

${ }^{\text {w}}$ Means within a column with different letters are significantly different from each other based on least significant difference mean separation procedures $(P \leq 0.05) . \mathrm{n}=5$.

${ }^{v}$ Means within a row that have a different number of stars are significantly different from each other based on least significant difference mean separation procedure $(P \leq 0.05)$.

Table 2. Physical properties of rain garden filter bed substrates.

\begin{tabular}{|c|c|c|c|c|c|c|c|}
\hline \multirow[b]{3}{*}{ Substrate $^{z}$} & \multicolumn{4}{|c|}{ Infiltration } & \multirow{3}{*}{$\begin{array}{c}\text { Hydraulic } \\
\text { conductivity } \\
\mathrm{K}\left(\mathrm{cm} \cdot \mathrm{min}^{-1}\right)\end{array}$} & \multirow{2}{*}{\multicolumn{2}{|c|}{ Moisture content }} \\
\hline & \multirow[b]{2}{*}{$\begin{array}{l}\text { Initial }^{\mathrm{y}} \\
\left(\mathrm{cm} \cdot \mathrm{h}^{-1}\right)\end{array}$} & \multirow{2}{*}{$\begin{array}{c}\text { End of } \\
\text { Season } 1 \\
\left(\mathrm{~cm} \cdot \mathrm{h}^{-1}\right)\end{array}$} & \multirow{2}{*}{$\begin{array}{c}\text { Beginning of } \\
\text { Season } 2 \\
\left(\mathrm{~cm} \cdot \mathrm{h}^{-1}\right)\end{array}$} & \multirow[b]{2}{*}{$\begin{array}{c}\text { Final } \\
\left(\mathrm{cm} \cdot \mathrm{h}^{-1}\right)\end{array}$} & & & \\
\hline & & & & & & $\begin{array}{c}\text { Initial } \\
(\%)\end{array}$ & $\begin{array}{c}\text { Final } \\
(\%)\end{array}$ \\
\hline Soil & $15.1 \mathrm{a}^{\mathrm{x}}$ & $4.2 \mathrm{~b}$ & $2.7 \mathrm{~b}$ & $7.5 \mathrm{a}$ & $15.6 \mathrm{a}$ & $20 \mathrm{a}$ & $40 \mathrm{a}$ \\
\hline Sand & $2.5 \mathrm{c}$ & $1.8 \mathrm{c}$ & $2.0 \mathrm{~b}$ & $2.8 \mathrm{~b}$ & $1.0 \mathrm{c}$ & $10 \mathrm{~b}$ & $30 \mathrm{~b}$ \\
\hline Slate & $6.0 \mathrm{~b}$ & $9.9 \mathrm{a}$ & $11.8 \mathrm{a}$ & $8.5 \mathrm{a}$ & $12.4 \mathrm{~b}$ & $10 \mathrm{~b}$ & $30 \mathrm{~b}$ \\
\hline ANOVA $^{\mathrm{w}}$ & 0.0001 & 0.0004 & 0.03 & 0.01 & 0.0001 & 0.0001 & 0.005 \\
\hline
\end{tabular}

${ }^{\mathrm{z} F i l t e r}$ bed substrate blends (v/v). Soil $=50 \%$ sandy loam, $50 \%$ pine bark; Sand $=80 \%$ sand, $15 \%$ clay and silt fines, $5 \%$ pine bark; slate $=80 \%$ expanded slate, $20 \%$ pine bark.

${ }^{\mathrm{y}}$ Initial infiltration $=7$ weeks after filling the rain gardens with substrate, pre-planting; end of Season 1 infiltration $=28$ weeks after filling the rain gardens with substrate with plants growing for $141 \mathrm{~d}$; beginning of Season 2 = with plants growing for $176 \mathrm{~d}$; final infiltration = with plants growing for $287 \mathrm{~d}$.

${ }^{\mathrm{x}}$ Means within a column with different letters are significantly different from each other based on least significant difference mean separation procedures $(P \leq 0.05)$. For infiltration $\mathrm{n}=8$, hydraulic conductivity $\mathrm{n}=4$, and for moisture content, $\mathrm{n}=24$ (Season 1 ) and $\mathrm{n}=12$ (Season 2).

${ }^{\text {w } A n a l y s i s ~ o f ~ v a r i a n c e . ~} P$ values given. substrate infiltration differed: sand continued to have the slowest infiltration, whereas slate had the quickest (Table 2). The increase in slate's infiltration rate from initial to the end of Season 1 may be the result of higher growth of roots in the slate substrate. Woody roots aid infiltration and drainage as water moves along the roots (Archer et al., 2002). At the beginning of Season 2, sand and soil had the slowest infiltration rate and slate the quickest. Sand always had the slowest infiltration, whereas soil and slate had higher rates at the final sampling and were not significantly different from each other. Infiltration rates between 2.25 and $5.04 \mathrm{~cm} \cdot \mathrm{h}^{-1}$ are best for removal of total suspended solids, hydrocarbons, metals, $\mathrm{P}$, and $\mathrm{N}$ (Hunt et al., 2012). All of the substrates in this study fall within these ranges except for soil with an initial infiltration of $15.1 \mathrm{~cm} \cdot \mathrm{h}^{-1}$ and sand with infiltrations of $1.8 \mathrm{~cm} \cdot \mathrm{h}^{-1}$ and $2.0 \mathrm{~cm} \cdot \mathrm{h}^{-1}$ at the end of Season 1 and beginning of Season 2, respectively.

Under saturated conditions (Ksat), stormwater moved through sand the slowest and soil the quickest (Table 2). Similarly, additions of composts to sand increased coarse particles and Ksat (Kraus et al., 2013). Moisture content, after drainage, was also greatest in soil initially ( 7 weeks after filling) and finally (48 weeks after filling) $287 \mathrm{~d}$ after planting. Interestingly, MCs after drainage of sand and slate were not different from each other although saturated hydraulic conductivity (Ksat) between these substrates was different. Sand and slate had similar total percentages of fine particle size (33\%), which can nest into large pores in the substrate and retain stormwater after drainage (Drzal et al., 1999). A $20 \%$ addition of compost to slate resulted in $\approx 30 \%$ fine particles and optimal Ksat and moisture retention (Kraus et al., 2013). Results here and those reported by Kraus et al. (2013) again indicate that these engineered substrates and their stormwater flow properties are best predicted by groupings of particles into coarse (6.3 to $2.0 \mathrm{~mm}$ ), medium (2.0 to $0.5 \mathrm{~mm})$, and fine $(0.5$ to $0.106 \mathrm{~mm}$ ) particle size ranges as described by Drzal et al. (1999). Bulk density was greatest in sand $\left(1.3 \mathrm{~g} \cdot \mathrm{cm}^{-3}\right)$ followed by slate $\left(0.9 \mathrm{~g} \cdot \mathrm{cm}^{-3}\right)$ and soil $\left(0.8 \mathrm{~g} \cdot \mathrm{cm}^{-3}\right)$ initially. Final BD was also greatest in sand $\left(1.3 \mathrm{~g} \cdot \mathrm{cm}^{-3}\right)$, yet showed no significant difference between soil and slate $\left(0.9 \mathrm{~g} \cdot \mathrm{cm}^{-3}\right.$ for both soil and slate). Sand's high BD likely contributed to the slow Ksat.

Substrate chemical properties. Substrates differed in humic matter (HM), CEC, base saturation (BS), $\mathrm{pH}$ and $\mathrm{P}, \mathrm{Ca}, \mathrm{S}, \mathrm{Mn}, \mathrm{Zn}$, and $\mathrm{Cu}$ concentrations initially and $\mathrm{HM}, \mathrm{CEC}, \mathrm{BS}$ and $\mathrm{P}, \mathrm{Ca}, \mathrm{S}, \mathrm{Mn}, \mathrm{Zn}$, and $\mathrm{Cu}$ concentrations at the end of the study (Table 3). Initially, soil had the highest HM and CEC, which was expected as a result of its high soil and pine bark contents $(50 \% \mathrm{v} / \mathrm{v})$. Sand had the lowest $\mathrm{HM}, \mathrm{CEC}, \mathrm{BS}$, and $\mathrm{pH}$ and slate had the most basic $\mathrm{pH}$ and highest BS initially. At the end of the study, soil continued to have the greatest HM content and CEC, whereas there were no significant differences between substrates for 
pH. the U.S. EPA (1998) recommends that all rain garden substrates have a $\mathrm{pH}$ between 5.5 and 6.5 to ensure optimum adsorption of pollutants. Sand's (4.8) and slate's (5.1) $\mathrm{pH}$ had fallen below this recommendation. All three substrates may have become more acidic as a result of the ammonium sulfate $(21-0-0$ 24) fertilizer that was added to the stormwater.

Soil and slate were not significantly different in $\mathrm{P}$ content and both were higher than sand, both initially and at the end of the study (Table 3). Ca and S (data not shown) contents were highest in slate initially as a result of the production process where low sulfur coal is used to heat and expand the slate and lime is added to remove $\mathrm{SO}_{2}$ from gasses during the firing process (Stalite Company, 2008). By the final sample, the Ca concentration of slate was similar to soil and both were higher than sand (Table 3). Slate also contained the greatest concentration of $\mathrm{Zn}$ and $\mathrm{Cu}$, whereas sand had the highest concentration of Mn.
Plant growth and visual analyses. All substrates appeared to have appropriate physical and chemical properties to support plant growth. Root and shoot growth of all species were generally not significantly affected by substrate (Table 4). For the three species (B. 'Duraheat', I. virginica, and J. effusus) in which shoot growth was affected by substrate, sand produced the greatest growth. With a few exceptions, most of the species performed well in the rain gardens regardless of the filter bed substrate. $J$. 'Frenzy' died, whereas $J$. effusus thrived. J. effusus and E. purpureum subsp. maculatum had a better visual appearance in sand than in soil and slate (data not shown). Eleven of the 16 species (B. nigra, $B$. 'Duraheat', $M$. virginiana, $M$. 'Sweet Thing', I. virginica, I. 'Henry's Garnet', J. effusus, $P$. 'Shenandoah', $H$. angustifolius, $H$. 'First Light', and E. purpureum subsp. maculatum) all performed very well in the rain gardens and should be recommended to the green industry.
Effluent nutrient analysis. After 6 weeks (13 July 2011), substrate affected the $\mathrm{N}$ concentration in the effluent discharged from the rain gardens with effluent from sand generally having the highest concentrations of $\mathrm{N}$ (Fig. 1). Effluent $\mathrm{N}$ concentrations from soil and slate were similar generally but lower than sand. The large decrease in nutrient concentrations from all substrates on 10 Aug. 2011 was most likely the result of a heavy rain $(23.4 \mathrm{~cm})$ just before stormwater treatment application. The high concentrations of $\mathrm{N}$ leaching from sand are possibly the result of the low CEC (Table 3), reduced retention of $\mathrm{NH}_{4}-\mathrm{N}$, and insufficient organic matter and anaerobic conditions (no internal saturation zone) to denitrify $\mathrm{NO}_{3}-\mathrm{N}$. Substrates with higher amounts of organic matter and saturated conditions were required to decrease $\mathrm{NO}_{3}$ levels (Dietz and Claussen, 2005; Hsieh and Davis, 2005; Hunt et al., 2006). Because soil

Table 3. Nutrient content of three rain garden filter bed substrates.

\begin{tabular}{|c|c|c|c|c|c|c|c|c|c|}
\hline Substrate $^{z}$ & $\begin{array}{c}\mathrm{HM}^{\mathrm{y}} \\
(\mathrm{g} / 100 \mathrm{cc})\end{array}$ & $\begin{array}{c}\text { CEC } \\
(\mathrm{meq} / 100 \mathrm{cc})\end{array}$ & $\begin{array}{l}\text { BS } \\
(\%)\end{array}$ & $\mathrm{pH}$ & $\begin{array}{c}\mathrm{P} \\
\left(\mathrm{mg} \cdot \mathrm{dm}^{-3}\right)\end{array}$ & $\begin{array}{c}\mathrm{Ca} \\
\left(\mathrm{mg} \cdot \mathrm{dm}^{-3}\right)\end{array}$ & $\begin{array}{c}\mathrm{Mn} \\
\left(\mathrm{mg} \cdot \mathrm{dm}^{-3}\right)\end{array}$ & $\begin{array}{c}\mathrm{Zn} \\
\left(\mathrm{mg} \cdot \mathrm{dm}^{-3}\right)\end{array}$ & $\begin{array}{c}\mathrm{Cu} \\
\left(\mathrm{mg} \cdot \mathrm{dm}^{-3}\right)\end{array}$ \\
\hline & & & & & Initial & & & & \\
\hline Soil & $0.4 \mathrm{a}^{\mathrm{x}}$ & $11.6 \mathrm{a}$ & $87.9 \mathrm{~b}$ & $6.4 \mathrm{~b}$ & $24.3 \mathrm{a}^{\mathrm{y}}$ & $1072.9 \mathrm{~b}$ & $26.7 \mathrm{c}$ & $2.3 \mathrm{~b}$ & $0.4 \mathrm{~b}$ \\
\hline Sand & $0.1 \mathrm{c}$ & $2.9 \mathrm{c}$ & $76.4 \mathrm{c}$ & $5.6 \mathrm{c}$ & $5.2 \mathrm{~b}$ & $310.3 \mathrm{c}$ & $87.3 \mathrm{a}$ & $0.8 \mathrm{c}$ & $0.4 \mathrm{~b}$ \\
\hline Slate & $0.2 \mathrm{~b}$ & $9.7 \mathrm{~b}$ & $96.8 \mathrm{a}$ & $7.1 \mathrm{a}$ & $23.4 \mathrm{a}$ & $1678.3 \mathrm{a}$ & $43.8 \mathrm{~b}$ & $6.3 \mathrm{a}$ & $4.6 \mathrm{a}$ \\
\hline \multirow[t]{2}{*}{ ANOVA $^{x}$} & 0.0001 & 0.0001 & 0.0001 & 0.0001 & 0.0001 & 0.0001 & 0.0001 & 0.0001 & 0.0001 \\
\hline & & & & & Final & & & & \\
\hline Soil & $0.6 \mathrm{a}$ & $12.0 \mathrm{a}$ & $87.0 \mathrm{a}$ & 6.1 & $38.3 \mathrm{a}$ & $1149.3 \mathrm{a}$ & $20.6 \mathrm{c}$ & $2.4 \mathrm{~b}$ & $0.5 \mathrm{~b}$ \\
\hline Sand & $0.2 \mathrm{c}$ & $3.0 \mathrm{c}$ & $63.8 \mathrm{~b}$ & 4.8 & $15.3 \mathrm{~b}$ & $274.3 \mathrm{~b}$ & $84.1 \mathrm{a}$ & $1.1 \mathrm{~b}$ & $0.6 \mathrm{~b}$ \\
\hline Slate & $0.3 \mathrm{~b}$ & $7.4 \mathrm{~b}$ & $81.3 \mathrm{a}$ & 5.3 & $32.2 \mathrm{a}$ & $1080.5 \mathrm{a}$ & $41.9 \mathrm{~b}$ & $7.3 \mathrm{a}$ & $5.3 \mathrm{a}$ \\
\hline ANOVA & 0.0001 & 0.0001 & 0.005 & NS & 0.02 & 0.0006 & 0.0001 & 0.0001 & 0.0001 \\
\hline
\end{tabular}

${ }^{\mathrm{z}}$ Filter bed substrate blends (v/v). Soil $=50 \%$ sandy loam, $50 \%$ pine bark; sand $=80 \%$ sand, $15 \%$ clay and silt fines, $5 \%$ pine bark; slate $=80 \%$ expanded slate, $20 \%$ pine bark.

${ }^{\mathrm{y}} \mathrm{HM}=$ humic matter; $\mathrm{CEC}=$ cation exchange capacity; $\mathrm{BS}=$ base saturation

${ }^{\mathrm{x}}$ Means within a column with different letters are significantly different from each other based on least significant difference mean separation procedures $(P \leq$ $0.05) . \mathrm{N}=36$.

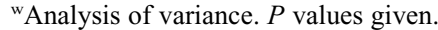

$\mathrm{P}=$ phosphorus; $\mathrm{Ca}=$ calcium; $\mathrm{Mn}=$ manganese $\mathrm{Zn}=$ zinc $; \mathrm{Cu}=$ copper.

NS $=$ nonsignificant.

Table 4. Dry weights for 16 different species for three different filter bed substrates.

\begin{tabular}{|c|c|c|c|c|c|c|c|c|c|c|c|c|c|c|c|}
\hline \multirow[b]{2}{*}{ Substrate $^{z}$} & \multicolumn{15}{|c|}{ Species evaluated } \\
\hline & $\mathrm{BN}^{\mathrm{y}}$ & BND & MV & MVST & IV & IVHG & $\mathrm{VN}$ & VNW & $\mathrm{JE}$ & PV & PVS & HA & HAFL & EPM & EPMG \\
\hline & \multicolumn{15}{|c|}{ Shoots (g) } \\
\hline Initials $^{\mathrm{x}}$ & 270.6 & 87.0 & 19.4 & 66.5 & 129.8 & 4.5 & 0.6 & 3.6 & 4.9 & 3.8 & 3.4 & 0.2 & 1.9 & 0.2 & 1.5 \\
\hline Sand & 5851 & $7847.1 \mathrm{a}^{\mathrm{w}}$ & 453.6 & 1224.7 & $680.4 \mathrm{a}$ & 136.1 & 45.4 & 45.4 & $362.9 \mathrm{a}$ & 1814.4 & 587.7 & 725.7 & 317.5 & 181.4 & 725.7 \\
\hline $\mathrm{OM}$ & 5488.5 & $4801.1 \mathrm{~b}$ & 362.9 & 544.3 & $499.0 \mathrm{~b}$ & 181.4 & 45.4 & 45.4 & $136.1 \mathrm{~b}$ & 1496.9 & 408.2 & 816.5 & 362.9 & 136.1 & 544.3 \\
\hline Slate & 5488.5 & $5307.0 \mathrm{~b}$ & 362.9 & 499.0 & $499.0 \mathrm{~b}$ & 136.1 & 45.4 & 18.1 & $181.4 \mathrm{~b}$ & 2041.2 & 725.7 & 771.1 & 453.6 & $\square^{\mathrm{u}}$ & 587.7 \\
\hline \multirow[t]{2}{*}{ ANOVA $^{v}$} & NS & 0.02 & NS & NS & 0.04 & NS & NS & NS & 0.04 & NS & NS & NS & NS & NS & NS \\
\hline & \multicolumn{15}{|c|}{ Roots (g) } \\
\hline Initials & 112.0 & 43.3 & 12.9 & 113.9 & 49.5 & 3.1 & 0.5 & 3.9 & 2.3 & 1.6 & 2.7 & 0.4 & 1.8 & 0.1 & 2.2 \\
\hline Sand & 1723.7 & 1995.8 & 136.1 & 589.7 & 362.9 & 45.4 & 45.4 & 45.4 & 317.5 & 2540.1 & 1496.9 & 136.1 & 45.4 & 90.7 & 499.0 \\
\hline $\mathrm{OM}$ & 1859.7 & 1723.7 & 181.4 & 362.9 & 272.2 & 45.4 & 45.4 & 18.1 & 136.1 & 1814.4 & 1088.6 & 136.1 & 181.4 & 136.1 & 453.6 \\
\hline Slate & 2086.5 & 1542.2 & 181.4 & 317.5 & 317.5 & 45.4 & 45.4 & 13.6 & 136.1 & 1496.9 & 1406.1 & 136.1 & 90.7 & - & 544.3 \\
\hline ANOVA & NS & NS & NS & NS & NS & NS & NS & NS & NS & NS & NS & NS & NS & NS & NS \\
\hline
\end{tabular}

${ }^{\mathrm{z} F i l t e r}$ bed substrate blends $(\mathrm{v} / \mathrm{v})$. Soil $=50 \%$ sandy loam, $50 \%$ pine bark; sand $=80 \%$ sand, $15 \%$ clay and silt fines, $5 \%$ pine bark; slate $=80 \%$ expanded slate, $20 \%$ pine bark.

${ }^{\mathrm{y}} \mathrm{BN}=$ Betula nigra $; \mathrm{BND}=$ Betula nigra 'Duraheat'; $\mathrm{MV}=$ Magnolia virginiana $; \mathrm{MVST}=$ Magnolia virginiana 'Sweet Thing'; IV = Itea virginica $; \mathrm{IVHG}=$ Itea virginica 'Henry's Garnet'; VN = Viburnum nudum; VNW = Viburnum nudum 'Winterthur'; JE = Juncus effusus; JEF = Juncus effusus 'Frenzy' (not shown as a result of death of all plants in all substrates); PV = Panicum virgatum; PVS = Panicum virgatum 'Shenandoah'; HA = Helianthus angustifolius; HAFL = Helianthus angustifolius 'First Light'; EPM = Eupatorium purpureum subsp. maculatum; EPMG = Eupatorium purpureum subsp. maculatum 'Gateway'. 'Initial samples taken just before planting.

${ }^{\text {w} M e a n s ~ w i t h i n ~ a ~ c o l u m n ~ w i t h ~ d i f f e r e n t ~ l e t t e r s ~ a r e ~ s i g n i f i c a n t l y ~ d i f f e r e n t ~ f r o m ~ e a c h ~ o t h e r ~ b a s e d ~ o n ~ l e a s t ~ s i g n i f i c a n t ~ d i f f e r e n c e ~ m e a n ~ s e p a r a t i o n ~ p r o c e d u r e s ~}(P \leq$ 0.05). For BN, BND, MV, and MVST n = 12; IV, IVHG, VN, VNW, HA, HAFL, EPM, and EPMH n = 24; and for JE, PV, and PVS n = 36.

${ }^{v}$ Analysis of variance. $P$ values given.

uneath of EPM occurred within the slate filter bed substrate.

NS $=$ nonsignificant. 
had 2.5 times more organic matter than slate ( $50 \%$ vs. $20 \%$ ), yet more similar CEC values (Table 3), CEC and retention of $\mathrm{NH}_{4}{ }^{+}$ appeared to reduce $\mathrm{N}$ concentration in effluent more than denitrification. Hunt et al. (2008) and Lucas and Greenway (2008) also found higher levels of nitrate/nitrite in their sandy loam substrate, which had 1.9 CEC and $0.3 \%$ organic matter. Another possible reason for the apparent lack of denitrification may be that anaerobic conditions did not persist in soil or slate substrates as a result of their rapid Ksat (Table 2). Hsieh et al. (2007a) concluded that a reduction of $\mathrm{NH}_{4}{ }^{+}-$ $\mathrm{N}$ to $\mathrm{NO}_{3}{ }^{-}-\mathrm{N}$ occurred as a result of slowing down infiltration.

Although $\mathrm{N}$ concentration applied to the stormwater was consistent throughout the study, $\mathrm{N}$ concentration in the effluent varied (Figs. 1 to 3). During Season 1 (0 to $141 \mathrm{~d}$ after planting), when plants were becoming established, $\mathrm{N}$ concentration in effluent from sand averaged $30.1 \mathrm{mg} \cdot \mathrm{L}^{-1}$, whereas soil and slate averaged $17 \mathrm{mg} \cdot \mathrm{L}^{-1}$ (Fig. 1). These reductions in $\mathrm{N}$ in the effluent are higher than those reported by Hunt et al. (2008) and Passeport et al. (2009) possibly as a result of enhanced plant growth in our study. Typical $\mathrm{N}$ and $\mathrm{P}$ concentrations in stormwater (Passeport et al., 2009) do not support rapid plant growth, whereas those used in this study did. Total $\mathrm{N}$ removal efficiencies [ $\mathrm{N}$ concentration in simulated runoff $-\mathrm{N}$ concentration in effluent $) \div \mathrm{N}$ concentration in simulated runoff] were affected by substrate for $33 \%$ of the treatment dates during Season 1. Slate and soil $(86 \%$ and $82 \%$ for slate and soil, respectively) had greater $\mathrm{N}$ removal than sand (64\%) (Fig. 1).

When plants were dormant (142 to $175 \mathrm{~d}$ after planting), $\mathrm{N}$ concentrations in the effluent were lower than during plant establishment (Season 1) with sand averaging 13 $\mathrm{mg} \cdot \mathrm{L}^{-1}$ and soil and slate averaging $8 \mathrm{mg} \cdot \mathrm{L}^{-1}$ (Fig. 2). Thus, plant nutrient uptake was still occurring even during winter months. Hunt et al. (2006) reported that rain gardens with an internal water storage zone (anaerobic) had an outflow with $4.38 \mathrm{mg} \cdot \mathrm{L}^{-1}$ total $\mathrm{N}$ as a result of denitrificaiton. Rain gardens in this experiment had higher influent $\mathrm{N}$ concentration, did not have internal water storage zones, and resulted in higher outflow $\mathrm{N}$ concentrations than those reported by Hunt et al. (2006). However, sand (with the slowest Ksat and lowest CEC) had greater N concentration in effluent than soil and slate, indicating again the importance of the CEC of the substrate in remediation.

During Season 2 (176 to $287 \mathrm{~d}$ after planting), when plants had sufficient time to grow roots into the substrates, there were fewer differences between substrates (Fig. 3). $\mathrm{N}$ concentrations in effluent from all three substrates averaged $\approx 10 \mathrm{mg} \cdot \mathrm{L}^{-1}$. $\mathrm{N}$ removal efficiencies were affected by substrate for $50 \%$ of the treatment events. Interestingly, during Season 2, soil had the greatest $\mathrm{N}$ removal $(87 \%)$ with slate and sand being lower $(82 \%$ and $78 \%$ for slate and sand, respectively) and not significantly different

Season One (0-141 days after planting)

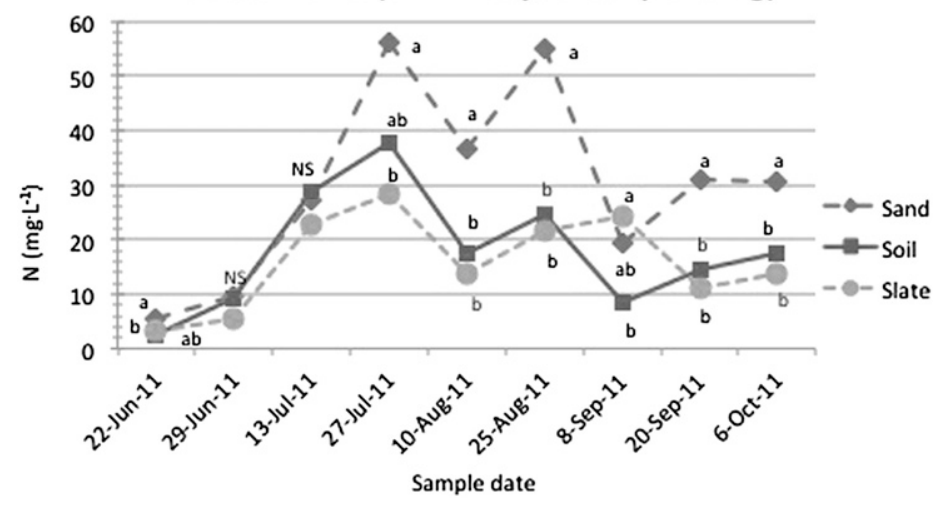

Fig. 1. Nitrogen $\left(\mathrm{NO}_{3}{ }^{-}+\mathrm{NO}_{2}{ }^{-}+\mathrm{NH}_{4}{ }^{+}\right)$analysis for filter bed substrates blends (v/v). Soil $=50 \%$ sandy loam, $50 \%$ pine bark; sand $=80 \%$ sand, $15 \%$ clay and silt fines, $5 \%$ pine bark; slate $=80 \%$ expanded slate, $20 \%$ pine bark by sample date for Season 1 . Means within substrates at a sample date are significantly different from each other based on least significant difference mean separation procedures $(P \leq 0.05)$. NS $=$ nonsignificant.

\section{Dormant Season (142-175 days after planting)}

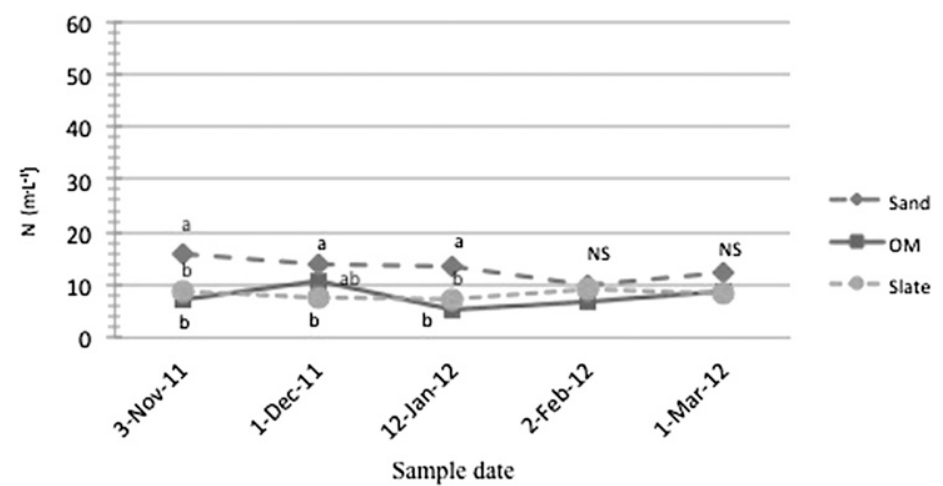

Fig. 2. Nitrogen $\left(\mathrm{NO}_{3}{ }^{-}+\mathrm{NO}_{2}{ }^{-}+\mathrm{NH}_{4}{ }^{+}\right)$analysis for filter bed substrates blends (v/v). Soil $=50 \%$ sandy loam, $50 \%$ pine bark; sand $=80 \%$ sand, $15 \%$ clay and silt fines, $5 \%$ pine bark; slate $=80 \%$ expanded slate, $20 \%$ pine bark by sample date for Season 1 . Means within substrates at a sample date are significantly different from each other based on least significant difference mean separation procedures $(P \leq 0.05)$. NS $=$ nonsignificant.

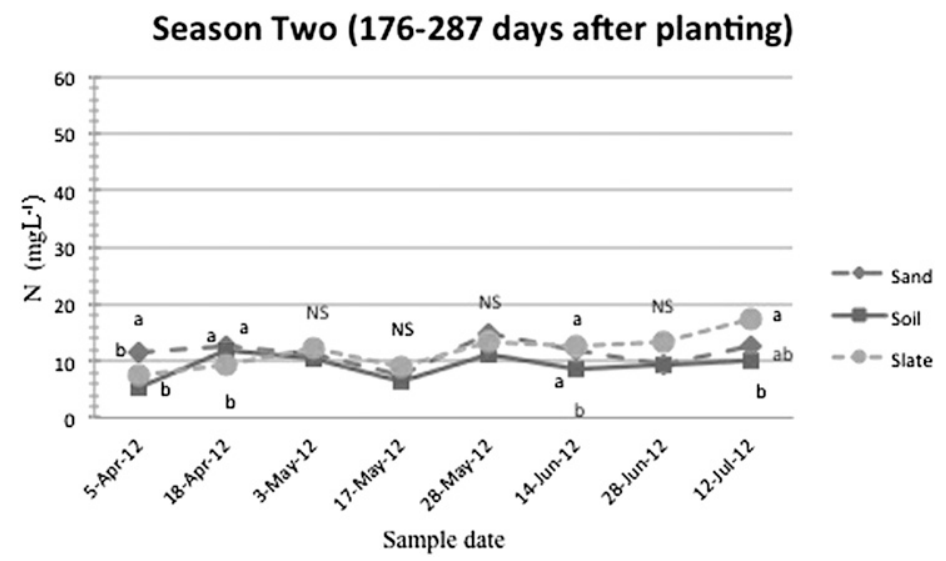

Fig. 3. Nitrogen $\left(\mathrm{NO}_{3}{ }^{-}+\mathrm{NO}_{2}{ }^{-}+\mathrm{NH}_{4}{ }^{+}\right)$analysis for filter bed substrates blends (v/v). Soil $=50 \%$ sandy loam, $50 \%$ pine bark; sand $=80 \%$ sand, $15 \%$ clay and silt fines, $5 \%$ pine bark; slate $=80 \%$ expanded slate, $20 \%$ pine bark by sample date for Season 1 . Means within substrates at a sample date are significantly different from each other based on least significant difference mean separation procedures $(P \leq 0.05)$. NS $=$ nonsignificant.

from each other. Soil had the highest moisture content and HM content, which could have increased denitrification in very small pores, which remain saturated even after drainage. Similar findings were reported by Lucas and Greenway (2008). 
For $55 \%$ of the simulated rainfall events, substrate affected $\mathrm{P}$ concentration in the effluent (Figs. 4 to 6). Similar to N, P in the effluent varied with time maintaining levels of $\approx 3 \mathrm{mg} \cdot \mathrm{L}^{-1}$ from initiation through the dormant season ( 0 to $175 \mathrm{~d}$ after planting) in the sand and soil substrates and $\approx 1 \mathrm{mg} \cdot \mathrm{L}^{-1}$ from slate (Figs. 4 and 5). Throughout Season 1 and the dormant season ( 0 to $175 \mathrm{~d}$ after planting), slate bound significantly more $\mathrm{P}$, reducing $\mathrm{P}$ concentrations in the effluent by $90 \%$ on average. The greater $\mathrm{P}$ retention by slate with a high $\mathrm{Ca}$ content (Table 3 ) is likely the result of $\mathrm{Ca}-\mathrm{PO}_{4}$ complexes removing the

\section{Season One (0-141 days after planting)}

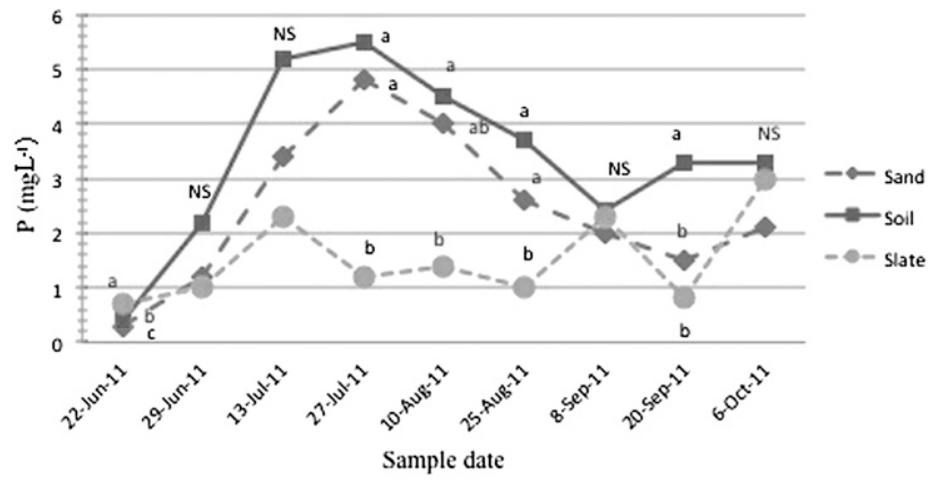

Fig. 4. Phosphorus analysis for filter bed substrate blends (v/v). Soil $=50 \%$ sandy loam, 50\% pine bark; sand $=80 \%$ sand, $15 \%$ clay and silt fines, $5 \%$ pine bark; slate $=80 \%$ expanded slate, $20 \%$ pine bark by sample date for Season 1. Means within substrates at a sample date are significantly different from each other based on least significant difference mean separation procedures $(P \leq 0.05)$. NS $=$ nonsignificant.

\section{Dormant Season (142-175 days after planting)}

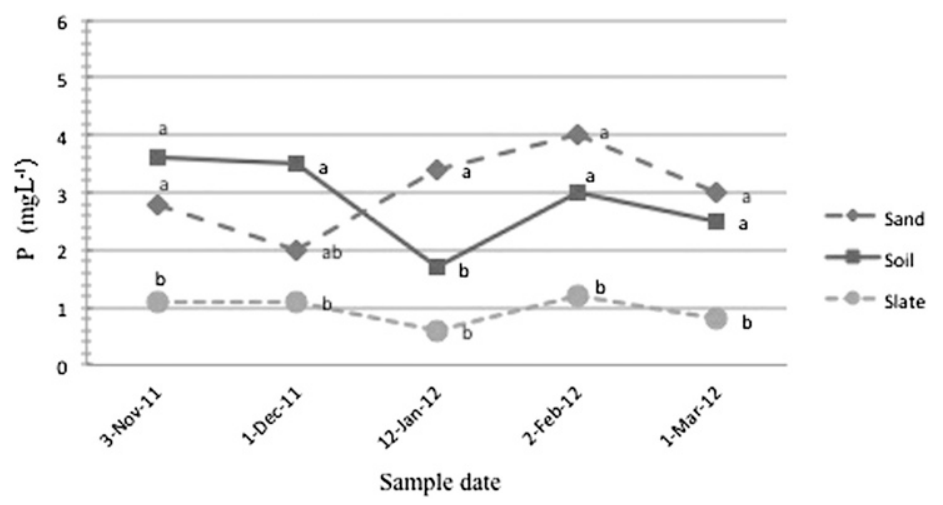

Fig. 5. Phosphorus analysis for filter bed substrates blends $(v / v)$. Soil $=50 \%$ sandy loam, $50 \%$ pine bark; sand $=80 \%$ sand, $15 \%$ clay and silt fines, $5 \%$ pine bark; slate $=80 \%$ expanded slate, $20 \%$ pine bark by sample date for Season 1. Means within substrates at a sample date are significantly different from each other based on least significant difference mean separation procedures $(P \leq 0.05)$. NS $=$ nonsignificant.

\section{Season 2 (176-287 days after planting)}

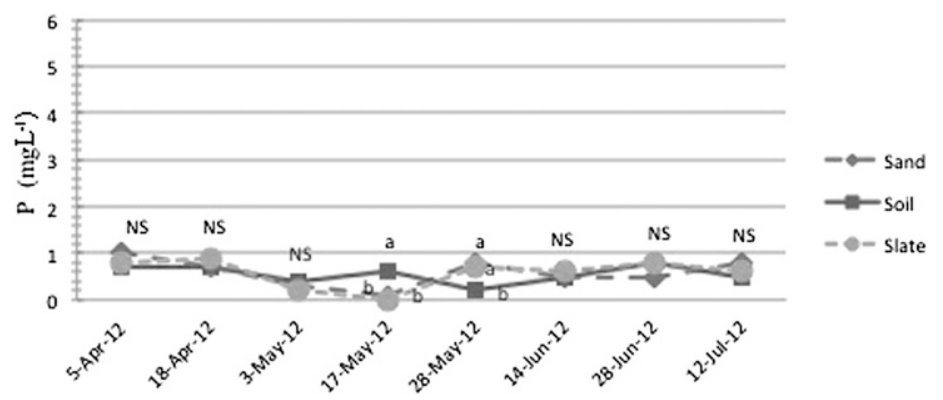

Fig. 6. Phosphorus analysis for filter bed substrates blends $(\mathrm{v} / \mathrm{v})$. Soil $=50 \%$ sandy loam, $50 \%$ pine bark; sand $=80 \%$ sand, $15 \%$ clay and silt fines, $5 \%$ pine bark; slate $=80 \%$ expanded slate, $20 \%$ pine bark by sample date for Season 1. Means within substrates at a sample date are significantly different from each other based on least significant difference mean separation procedures $(P \leq 0.05)$. NS $=$ nonsignificant.

soluble $\mathrm{PO}_{4}$ and the formation of insoluble $\mathrm{CaPO}_{4}$ precipitates (Mengel and Kirkby, 1982). Hsieh et al. (2007a) and Lucas and Greenway (2008) reported higher P remediation when cation- $\mathrm{PO}_{4}$ complexing occurred, especially with established plant growth. During Season 2 (176 to $287 \mathrm{~d}$ after planting), $P$ concentrations in the effluent decreased substantially (to near $0.5 \mathrm{mg} \cdot \mathrm{L}^{-1}$ ) for all substrates and few differences between substrates were found (Fig. 6) indicating that either plant $\mathrm{P}$ uptake or substrate adsorption, or both, nearly equaled the $\mathrm{P}$ in the simulated runoff. These effluent $\mathrm{P}$ concentrations are $0.37 \mathrm{mg} \cdot \mathrm{L}^{-1}$ higher than those reported by Hunt et al. (2008) in which inflow P concentrations onto a vegetated rain garden averaged $0.19 \mathrm{mg} \cdot \mathrm{L}^{-1}$. Throughout this study, soil and sand substrates generally had higher concentrations of $\mathrm{P}$ in the effluent as a result of the higher $\mathrm{P}$ contents of these substrates (Table 3). Hunt et al.'s (2006) reported similar findings. Interestingly, for seven of the $13(54 \%)$ treatment events where substrate affected $\mathrm{P}$ concentration in the effluent, the sand and soil substrates were not significantly different from each other although the soil had much higher $P$ content than the sand substrate (Table 3 ).

In this study, substrate affected concentrations of $\mathrm{K}, \mathrm{Ca}, \mathrm{Mg}$, and sodium in the effluent for sand throughout the study, whereas substrate's effect on $\mathrm{Fe}, \mathrm{Mn}, \mathrm{Zn}, \mathrm{Cu}, \mathrm{B}$, and chlorine were less consistent over time (data not shown). $\mathrm{Mn}$ and $\mathrm{Zn}$ in the effluent were highest with the sand substrate (data not shown). The slate had the greatest concentrations of $\mathrm{Ca}, \mathrm{S}, \mathrm{Cu}$, and $\mathrm{B}$ in the effluent (data not shown) as a result of the initial content of these elements in this substrate (Table 3 and data not shown). Soil also resulted in high concentrations of $\mathrm{Mg}$ and $\mathrm{Fe}$ in the effluent (data not shown). Davis et al (2001) states that soils have a large attraction to metals and a sand-based substrate $(\approx 75 \%$ sand, $9 \%$ clay, and $17 \%$ silt) had high removal of metals with a $\mathrm{pH} \approx 7$. The sand substrate used in this research did not bind metals as well as the slate substrate most likely as a result of the $\mathrm{pH}$ being at or below 5 (Table 4). In this research, slate had an initial $\mathrm{pH}$ of 7.1 and final of 5.3, and sand had a $\mathrm{pH}$ of 5.6 and 4.8 initially and at the end of the study, respectively, supporting Davis et al.'s (2001) findings.

\section{Conclusions}

Coarse-textured particles (6.3 to $2.0 \mathrm{~mm}$ ) appeared to create a large pore network that conducted stormwater into and through the substrates. Slate had the greatest percentage of medium-range ( 2.0 to $0.5 \mathrm{~mm}$ ) particles, which may have increased overall substrate porosity slowing saturated hydraulic conductivity and initial infiltration rate compared with soil. However, infiltration in slate increased over time, whereas soil's decreased and sand's remained constant. Even with high infiltration and Ksat, slate performed the best in retention of $\mathrm{N}$ and $\mathrm{P}$. The sand 
substrate had good overall retention of nutrients, except N, possibly as a result of the very small percentage $(5 \%)$ of organic matter and low CEC and P. Hsieh et al. (2007a), Hunt et al. (2006, 2008), and Passeport et al. (2009) all showed similar results with poor retention of $\mathrm{NO}_{3}{ }^{-}-\mathrm{N}$ in their substrates all relating to low amounts of biological activity. Additionally, sand had a very acidic pH (4.8), which may have decreased nitrification. Soil did not fluctuate much in remediation of $\mathrm{N}$, having $82 \%$ removal in Season 1 and concluding with $86 \%$ removal in Season 2. Slate had the best overall retention of $\mathrm{N}$, having $86 \%$ removal initially and $99 \%$ removal by the end of the study. In regard to $P$, slate and sand had the best overall remediation, $99 \%$ and $96 \%$, respectively. Initially, all three substrates reduced levels of $\mathrm{Zn}$ (sand: $96 \%$, soil: $94 \%$, slate: $98 \%$ ), but by the end of the study, remediation decreased (sand: 92\%, soil: $82 \%$, and slate: $86 \%$ ). The opposite was true for $\mathrm{Fe}$. Substrate removed little $\mathrm{Fe}$ initially (sand: $48 \%$, soil: $68 \%$, slate: $69 \%$ ), but remediation increased by the termination of the study (sand: $84 \%$, soil: $87 \%$, slate: $82 \%$ ). The $\mathrm{pH}$ decreased for all three substrates as the study progressed, which provided less desirable adsorption for metals. Remediation by all three substrates appeared to level out by Season 2 (176 d after planting) and there were fewer differences between substrates indicating that plant uptake was controlling remediation. The importance of plant involvement for remediation is also expressed in work done by Blecken et al. (2009a, 2009b), Brateries et al. (2008), Lucas and Greenway (2008), and Read et al. (2008).

\section{Literature Cited}

Archer, N.A.L., J.N. Quinton, and T.M. Hess. 2002. Below-ground relationships of soil texture, roots, and hydraulic conductivity in twophase mosaic vegetation in south-east Spain. J. Arid Environ. 52:535-553.

Blecken, G.T., Y. Zinger, A. Deletic, T.D. Fletcher, and M. Viklander. 2009a. Influence of intermittent wetting and drying conditions on heavy metal removal by stormwater biofilters. Water Res. 43:4590-4598.

Blecken, G.T., Y. Zinger, A. Deletic, T.D. Fletcher, and M. Viklander. 2009b. Impact of a submerged zone and a carbon source on heavy metal removal in stormwater biofilters. Ecol. Eng. 35:769-778.

Brateries, K., T.D. Fletcher, A. Deletic, and Y. Zinger. 2008. Nutrient and sediment removal by stormwater biofilters: A large-scale design optimization study. Water Res. 42:3930-3940.

Carpenter, S.R., N.F. Caraco, D.L. Correll, R.W. Howarth, A.N. Sharpley, and V.H. Smith. 1998. Nonpoint source pollution of surface waters with phosphorus and nitrogen. Ecol. Appl. 8:559-568.

Davis, A.P., W.F. Hunt, R.G. Traver, and M.E. Clar. 2009. Bioretention technology: An overview of current practice and future needs. J. Environ. Eng. 135:109-117.

Davis, A.P., M. Shokouhian, H. Sharma, and C. Minami. 2001. Laboratory study of biological retention for urban stormwater management. Water Environ. Res. 78:284-293.

Dietz, M.E. and J.C. Claussen. 2005. A field evaluation of rain garden flow and pollutant treatment. Water Air Soil Pollut. 167:123-138.

Drzal, M.S., W.C. Fonteno, and D. Keith Cassel. 1999. Pore fraction analysis: A new tool for substrate testing. Proc. Int. Sym. Growing Media and Hydroponics. Ed. A.P. Papadopoulos. Acta Hort. 481:43-54.

Glasgow, H.B., J.M. Burkholder, M.A. Mallin, N.J. Deamer-Melia, and R.E. Reed. 2001. Field ecology of toxic Pfiesteria complex species and a conservative analysis of their role in estuarine fish kills. Environ. Health Perspect. 109(suppl. 5):715.

Glass, C. and S. Bissouma. 2005. Evaluation of a parking lot bioretention cell for removal of stormwater pollutants. Ecosystems and sustainable development V. WIT, Southampton, UK. p. 699-708.

Hsieh, C. and A.P. Davis. 2005. Evaluation and optimization of bioretention media for treatment of urban storm water runoff. J. Environ. Eng. 131:1521-1531.

Hsieh, C., A.P. Davis, and B.A. Needelman. 2007a. Bioretention column studies of phosphorus removal from urban stormwater runoff. Water Environ. Res. 79:177-184.

Hsieh, C., A.P. Davis, and B.A. Needelman. $2007 \mathrm{~b}$. Nitrogen removal from urban stormwater runoff through layered bioretention columns. Water Environ. Res. 79:2404-2411.

Hunt, W.F., A.P. Davis, and R.G. Traver. 2012 Meeting hydrologic and water quality goals through targeted bioretention design. J. Environ. Eng. 138:698-707.

Hunt, W.F., A.R. Jarrett, J.T. Smith, and L.J. Sharkey. 2006. Evaluating bioretention hydrology and nutrient removal at three field sites in North Carolina. J. Irrig. Drain. Eng. 132(6): 600-608.

Hunt, W.F., J.T. Smith, S.J. Jadlocki, J.M. Hathaway, and P.R. Eubanks. 2008. Pollutant removal and peak flow mitigation by a bioretention cell in urban Charlotte, NC. J. Environ. Eng. 134:403408.

Kempers, A. J. and A.G. Luft. 1988. Re-examination of the determination of environmental nitrate by reduction with hydrazine. Analyst (Lond.) 113:1117-1120.

Kim, H., E.A. Seagren, and A.P. Davis. 2003. Engineered bioretention for removal of nitrate from storwmater runoff. Water Environ. Res. 74:355-367.

Kraus, H., T. Bilderback, R. Pledger, E. Riley, B. Fonteno, and B. Jackson. 2013. Defining rain garden filter bed substrates based on saturated hydraulic conductivity. Proc. Int. Sym. Growing Media and Hydroponics. Ed. A.P. Papadopoulos. Acta Hort. (in press).

Krom, M.D. and R.A. Bemer. 1980. Adsorption of phosphate in anoxic marine sediments. Limnol. Oceanogr. 25:797-806.

Lucas, W.C. and M. Greenway. 2008. Nutrient retention in vegetated and nonvegetated bioretention mesocosms. J. Irrig. Drain. Eng. 143:613-623.

Mengel, K. and E.A. Kirkby. 1982. Principles of plant nutrition. International Potash Institute, Worblaufen-Bern, Switzerland.

North Carolina Division Environment and Natural Resources. 2007. Stormwater best management practice manual. <http://portal.ncdenr.org/web/ $\mathrm{wq} / \mathrm{ws} / \mathrm{su} / \mathrm{bmp}>$.

Passeport, E., W.F. Hunt, D.E. Line, R.A. Smith, and R.A. Brown. 2009. Field study of the ability of two grassed bioretention cells to reduce storm-water runoff pollution. Irrigation and Drainage Engineering 135:505-510.

Read, J., T. Wevill, T. Fletcher, and A. Delectic. 2008. Variation among plant species in pollutant removal from stormwater in biofiltration systems. Water Res. 42:893-902.

SAS Institute, Inc. 2001. SAS/STAT user's guide: Release 9.2 edition. SAS Inst., Inc., Cary, NC. Skalar Analytical, B.V. 1995a. Ammonium. In: The $\mathrm{SAN}^{++}$segmented flow analyzer-Water analysis. Skalar Analytical B.V., Breda, The Netherlands. p. 73-75.

Skalar Analytical, B.V. 1995b. Nitrate + nitrite. In: The $\mathrm{SAN}^{++}$segmented flow analyzer-Water analysis. Skalar Analytical B.V., Breda, The Netherlands. p. 190-192.

Stalite Company. 2008. Stalite's rotary kiln process. Stalite Lightweight Aggregate web site. 8 Nov. 2012. <http://www.stalite.com/ stalite-production.php?cat $=45>$.

Sun, X. and A.P. Davis. 2007. Heavy metal fates in laboratory bioretention systems. Chemosphere 66:1601-1609.

Taylor, G.D., T.D. Fletcher, T.H.F. Wong, P.F. Breen, and H.P. Duncan. 2005. Nitrogen composition. I. Urban runoff-implications for stormwater management. Water Res. 39:1982-1989.

U.S. Environmental Protection Agency (U.S. EPA). 2009. National water quality inventory: Report to Congress. EPA-841-R-08-001.

U.S. Environmental Protection Agency (U.S EPA). 1998. Stormwater technology factsheet. EPA-832-F-99-012. 